\title{
10. Institutional renewal and reform: the challenge of the Commonwealth of Nations
}

\author{
The Hon. Michael Kirby
}

In July 2010, I was appointed to the Eminent Persons Group (EPG) established by the Commonwealth Heads of Government Meeting (CHOGM) held in Trinidad and Tobago in 2009. At that meeting were gathered the leaders of the 53 Commonwealth nations. They decided to establish the EPG in order to investigate, and report on, the essential ingredients of reform to the institutional arrangements of this global family of Commonwealth nations. There was a sense that in this era of institutional reform, there might be lessons applicable to the Commonwealth of Nations for the attainment of desirable identified objectives. At the least, this global challenge will identify some of the impediments that must be overcome if lasting reform is to be attained. This is always a complex and challenging task when it involves the creation of new structures and the disturbance of long-settled and comfortable ways.

This chapter will address the challenge of reforming the Commonwealth of Nations. I want first to examine some of the institutions that make up the Commonwealth of Nations, to identify the important role that these institutions play in a reform process, and to examine the new initiatives that will be necessary to assist the Commonwealth of Nations as it undertakes the present process of renewal. I will reflect briefly on the options for institutional reform of the Commonwealth generally and, of course, the views that I express are my own and not those of the EPG.

Second, I will seek to examine the importance of the common values that are probably still shared in the former British Commonwealth. Historically, this organisation has evidenced success both in changing and evolving its own characteristics and in influencing change in member countries where a clear and coherent voice can be found to that effect. The struggle against the oppressive apartheid regime in South Africa, and its later counterpart in Rhodesia (now Zimbabwe), constitutes an example of such success. I will show, however, that the Commonwealth has not always found a commonality of will in facing later challenges. In particular, the failure of the Commonwealth to adequately address serious human rights problems in member countries is an example of where the organisation has fallen short of the defence of the values that it ostensibly espouses. 
My purpose is ultimately twofold: first, to demonstrate that the process of institutional renewal and ongoing reform is critical to ensuring effective policy development and implementation in the organisation in question. Second, I hope to show the importance of the constant evaluation and re-evaluation of policy objectives, based on identified institutional values. Only if those objectives are clear and coherent will true reform be proposed, sharpened, put in concrete form, delivered and maintained.

\section{Shared British history and dialogue}

The Commonwealth of Nations grew out of the British Empire - the largest, most diverse and successful imperial exercise in human history. The sun never set on the Empire in its heyday, early in the twentieth century. It comprised more than one-quarter of the land surface of the world and about one-third of its population; it was truly a time when the Royal Navy ruled the waves. Australians of my age grew up in the last decades of the British Empire, after it had survived the challenges of its enemies in World War II. Every 24 May, on Queen Victoria's birthday, my school celebrated Empire Day. It was to some extent a triumphant reminder of the warrior character of the British race, of its economic, intellectual and industrial inventiveness, of its strong institutions of law and government, and of its sense of racial superiority and destinyultimately shattered only by the drain on its manpower and treasure in the global war of 1939-45.

The Commonwealth of Nations was eventually formed in April 1949 to replace the British Empire and British Commonwealth. It was then, at the Commonwealth Prime Ministers' meeting attended by Ben Chifley of Australia, that the formula was worked out between Earl Attlee and Jawaharlal Nehru whereby India could remain a member of the Commonwealth without allegiance of its citizens to the British Crown. Until then, it was that allegiance that had been the cement that kept the British family of nations together. Unwilling to accord allegiance, Ireland departed, as earlier the United States of America had done. But in an inventive solution, it was agreed that thereafter the Commonwealth would be a community based on 'free association'. The British Monarch would be accepted as a symbolic head. In this way, King George VI added the title 'Head of the Commonwealth' to his royal titles. On the accession of Queen Elizabeth II, she was recognised as Head of the Commonwealth, an office she takes most seriously (Mayall 2010:26). In witness of this role, the first meeting of the EPG, held in London in July 2010, concluded with an audience with the Queen, as Head of the Commonwealth, at Buckingham Palace. 
Various former links that once held the Empire and early Commonwealth together successively fell away, including judicial appeals to the Privy Council-finally ended in Australia in 1986 (Australia Acts 1986 [Cwlth and UK]:s. 6) and in New Zealand in 2003 (Supreme Court Act 2003 [NZ]). In addition, Commonwealth preference in trade declined after the 1960s. In a recent speech to the Commonwealth Legal Forum, Sir Shridath Ramphal, second SecretaryGeneral, declared that 'Language, Learning and Law; these three are the most precious heritage of the Commonwealth; but the greatest of these is law' (Ramphal 2010:359).

Certainly, these are the fields in which, over my professional life, I have come to know and appreciate the work of the Commonwealth and of its Secretariat housed in the royal palace of Marlborough House in London.

There are nearly 100 associations that have the word 'Commonwealth' in their name. They bring together professional, institutional and other colleagues whose nations have substantially shared the experience of British rule and institutions. The Commonwealth Parliamentary Association, for example, taps the deep reservoir of experience found in the legislatures of Commonwealth nations. Because one of the core values of the Commonwealth is accepted to be electoral democracy, it is natural that the nations that substantially follow the traditions derived mainly from the British parliamentary legacy should find unity in an ongoing conversation between parliamentarians of Commonwealth nations.

As well as establishing the EPG, the Affirmation agreed at the 2009 CHOGM conference contains an extensive elaboration of the belief of the Commonwealth in 'the inalienable right of the individual to participate by means of free and democratic processes in shaping the society in which they live' (CHOGM 2009:12). The same document recognises that parliaments and representative local government and other forms of local governance are essential elements in the exercise of democratic governance'. Today such legislatures also participate in the Inter-Parliamentary Union (IPU) with its broader global membership and operation. There is, however, something especially comfortable and friendly in a meeting of personnel who share a common language, common history, many common institutions, common laws, common traditions and interests. Often these are unspoken. Sometimes they are even unconscious. But enough survive to make the dialogue capable of proceeding without so many adjustments for the differences that must be recognised in the United Nations and other circles.

In addition to professional and governmental bodies, and the regular meetings of ministers of Commonwealth nations holding similar portfolios, a very large number of civil-society organisations that have flourished within the Commonwealth enjoys representative bodies that focus on this connection. 
Thus, the Royal Commonwealth Society (RCS) plays an important function in stimulating and maintaining the lines of connection that exist within the Commonwealth. In recent times, the RCS has taken a lead in exploring the attitudes of Commonwealth citizens and their knowledge concerning the Commonwealth, their criticisms of present arrangements, and their suggestions for the ways in which the Commonwealth links could be strengthened (Royal Commonwealth Society 2009).

Last year, the RCS conducted a so-called 'Commonwealth Conversation'. It was a hard-talking, candid, disparate and impressive dialogue identifying what is wrong in the Commonwealth and how its citizens might go about trying to improve it. A repeated feature of the comments that emerged was a criticism that the 'Commonwealth is just too timid; that's the problem' (Royal Commonwealth Society 2009:20); that 'the Commonwealth isn't serious about human rights' (p. 23), and that it must be more articulate and forthright in declaring what its values are and establishing frameworks to hold the member nations and their citizens to their obligations of upholding the shared values proclaimed at regular meetings of CHOGM (p. 24).

I cannot think of a single other international organisation that would welcome, encourage and support such a critical and public introspection about its own strengths and weaknesses. In the final published version of the RCS document, the Secretary-General of the Commonwealth, Kamalesh Sharmar, welcomed the enterprise. He said:

I support the Commonwealth Conversation. It is extremely important that discourse takes place within the Commonwealth so that it is no longer seen as working along rigid paths or as being something belonging to the past, rather than something that belongs to the future. A future that is being shared. A future that is being shaped through discourse about expectations and possibilities. (Royal Commonwealth Society 2009:6) ${ }^{1}$

In some ways, the RCS seized an opportunity and took an initiative akin to the intensive public consultations in which the Australian Law Reform Commission engaged under my leadership in the 1970s and 1980s. The commitment that this then extracted from the Secretary-General is a welcome and fresh approachcertainly unusual in international agencies. It has also been welcomed by participants in the Commonwealth Conversation. In my opinion, there must be more such dialogue (Royal Commonwealth Society 2009:6).

\footnotetext{
1 Also see the very candid conversations in the Report of the Commonwealth Round Table Conference. See The Round Table, vol. 99, no. 408 (June 2010): “'A great global good?" Reviewing the modern Commonwealth' by Stuart Mole, pp. 321-4; and especially the contribution by Anwar Choudhury, p. 23.
} 
There have been several investigations of ways to revamp the Commonwealth and to improve its institutional structure. A common theme of past inquiries has been the emphasis placed on the need to improve performance of the secretariat in London. This was recognised by CHOGM in 2009. The Port of Spain Affirmation expressed a demand for

efforts to improve the Secretariat's governance, its responsiveness to changing priorities and needs, and its ability to enhance the public profile of the organisation. We commit ourselves to supporting the Secretariat in this endeavour. We also underline the importance we attach to intensifying the Secretariat's commitments to strategic partnerships with other international organisations and partners in order to promote the Commonwealth's values and principles. (CHOGM 2009:par. 14)

By the standards of other international agencies (even of the much less effective French rival, La Francophonie), the Commonwealth Secretariat is small in size, diverse in background and varied in experience. Observers sometimes complain about the variability of performance and the inordinate delays in addressing communications. Whatever the reasons, the need for improvement in the secretariat is clear. The inability in the RCS poll of two-thirds of those interviewed to name a single activity that the Commonwealth undertakes was especially discouraging (Llango, 2009:2.). At least one might have expected citizens to name the Commonwealth Games!

The ways forward for Commonwealth renewal were suggested in part by the CHOGM leaders themselves in establishing the EPG and affirming the Commonwealth values and, in part, by the suggestions of the RCS and other commentators. Common themes in contemporary proposals include

- the need for the Commonwealth to prioritise its activities more effectively

- the need to concentrate on those activities that the Commonwealth does best without replicating the activities done elsewhere by the United Nations, the G20, the Organisation for Economic Cooperation and Development (OECD) and so forth

- the need to avoid the delusion that the Commonwealth can be a global fulcrum for political, business, educational, economic, human rights and developmental activities

- the need to embrace greater openness in the bureaucratic style of the Commonwealth, which, in some ways, reflects the old colonial tradition of secrecy and non-transparency

- above all, the need to walk the walk, and not just talk the talk of so-called 'Commonwealth values'. 
Several countries of the Commonwealth have been seriously in default in their maintenance of the core values of electoral democracy, independence of the judiciary, and adherence to fundamental human rights. Yet in the past, little or nothing has been done by the Commonwealth or its Secretariat to redress these defects.

\section{Searching for shared values}

In repeated meetings of $\mathrm{CHOGM}$, the leaders of the Commonwealth governments have attempted to state the values for which the Commonwealth stands and which are 'guaranteed' for their citizens. Thus, in 1971, the statement of the Singapore CHOGM affirmed a strong stand against racism and, in particular, apartheid - then dominant in the Government of South Africa. There is little doubt that the pressure from the Commonwealth and facilitation by an earlier EPG hastened the demise of that regime and the return of a democratic South Africa to the Commonwealth table.

In 1991, in Harare - in happier times in Zimbabwe - the CHOGM meeting contained an assertion of the centrality of

[d]emocracy, democratic processes and institutions which reflect national circumstances, just and honest government and fundamental human rights, the rule of law and the independence of the judiciary, freedom of expression and the enjoyment of such rights by all individuals regardless of gender, race, colour, creed or political belief (Oke 2008).

These statements were in turn reaffirmed in 1995 by the Millbrook Declaration adopted during the Auckland CHOGM. That declaration accepted the need for improved machinery in the Commonwealth by a subcommittee of foreign ministers in the Commonwealth Ministerial Action Group (CMAG). It was hoped that CMAG could respond quickly to perceived dangers to, or departures from, declared Commonwealth values. This body was declared to be the 'custodian of the Commonwealth's fundamental political values' (CHOGM 2009:pars 8, 10; see also Commonwealth High Level Review Group 2002). Whilst it has been partly effective in responding to the military takeover of elected regimes (for example, Fiji) and to serious infractions in democratic elections (for example, Zimbabwe), CMAG has been far less effective in investigating and responding to persistent abuses of civil, political, economic, social and cultural rights for all. Sometimes, despite the rhetoric, the inhibition of non-interference in domestic affairs seems to have been at work. Yet if that rule still prevailed in the Commonwealth, South Africa would still be an apartheid state. 


\section{The human rights challenges facing the EPG}

This, then, is the challenge that currently faces the EPG. Although the United Kingdom is a nuclear power, it has neither the means nor the will to reassert imperial rule. On the contrary, the United Kingdom has never had the fascination for the Commonwealth or its former imperial legacy that many had in the Commonwealth nations themselves. The growth since 1949 of countless international agencies and groupings, of the power and influence of the United Nations, and of economics as a precondition for good governance and effective achievement of human rights make the challenge before the EPG today a very large one.

Nonetheless, if we look to those times in the past when the Commonwealth has been most effective, they would undoubtedly include the times when the Commonwealth could agree on a significant moral cause based on Commonwealth 'values' founded in the essential notions of human dignity shared by people everywhere. The Commonwealth was never stronger than in responding to the oppression against people on the ground of their race in the southern African countries that had been part of the British Empire. The question now is whether-grounded in the strong assertions of fidelity to universal human rights - the Commonwealth can recapture the same unity of purpose around basic ethical principles. And whether it can revamp its institutional structures to ensure the attainment of the goals so eloquently stated, and restated, in successive CHOGM declarations.

If the Commonwealth is to be simply a congenial club of mostly middle-aged men who attend its meeting every second year, enjoy the royal ambiance and then depart to continue oppressive regimes, it will probably fade awayperhaps deservedly so. Yet that would be a tragedy for the utility of the official, professional and other shared experiences that the Commonwealth facilitates, and for the utility of having an organisation of 54 states of all sizes and degrees of power, which can meet together in comparative friendship and harmony and share experiences and viewpoints on a basis that (formally at least) is one of equality and mutual respect.

One ethical issue upon which the Commonwealth of Nations has evidenced an obvious blind spot is a peculiar legacy of British rule. I refer to the antihomosexual laws that remain in place in 41 of the 54 member countries of the Commonwealth. In our world of nearly 200 nation-states, only 86 states still criminalise consensual same-sex acts in private involving adults. And nearly half of those states are members of the Commonwealth. This is because the common and statute law of Britain in colonial times imposed a criminal offence for such conduct throughout the Empire. Napoleon's codifiers had abolished the 
offence in France in 1803. The result of that action was that the countries that derived their penal codes from the codifiers (France, Spain, the Netherlands, Belgium, Germany, Russia and Scandinavia) never exported the sodomy offence to their colonies. So this was a peculiar British export. And whereas the United Kingdom and the older Commonwealth members have repealed such laws during the past 40 years, they remain firmly in place in most developing countries of the Commonwealth of Nations.

In Zimbabwe (presently suspended from the Commonwealth), President, Robert Mugabe, has voiced many attacks on homosexual citizens, describing them as 'un-African' and 'worse than dogs and pigs'. Reportedly, he told crowds: 'we are against homosexuality and we as chiefs in Zimbabwe should fight against such Western practices and [demand that they] respect our culture.' (Johnson and Walker 2000). At the same time, former Kenyan President Daniel arap Moi declared homosexuality was 'against African tradition and biblical teaching'. In Zambia, a government spokesman in 1998 declared that it was 'an abomination to society'. The previous President of Nigeria, Olusegun Obasanjo, in 2004, declared that it was 'definitely un-African' (BBC news online 2004). In Malaysia, Section 377 of the country's penal code has been invoked twice to prosecute former Deputy Prime Minister and now opposition leader Anwar Ibrahim. The potential for misuse of this law is large. Its impediment to the battle against HIV/ AIDS is significant. The attempts to reform the law in Commonwealth countries have failed. Even in modern Singapore, where the former Prime Minister Lee Kwan Yew supported the reform, the legislature rejected a Law Society proposal for reform. The government contented itself by saying there would be no prosecutions. But the law remains on the books to harass, shame, belittle and endanger citizens.

In Malawi, two young men were sentenced in 2010 to 14 years' imprisonment on conviction of sodomy following the conduct of a symbolic 'wedding' - probably only a party. Only the intervention of the Secretary-General of the United Nations led to a presidential pardon (see, for example, Husain 2010). In Uganda, a bill has been introduced that, if enacted, would impose the death penalty for various homosexual acts. ${ }^{2}$ Despite this sorry record, the Commonwealth Secretariat has publicly remained silent and apparently inert and ineffective. It has been left to UN officials to take the running in defence of the human rights that are repeatedly declared as core values of the CHOGM declarations.

In the face of populist politics, religious passions, spiritual competitions between religions, alleged cultural and regional attitudes and unwise public health strategies, how does a body such as the Commonwealth of Nations find

2 Opinion for Commonwealth Lawyers' Association by Mr Timothy Otty QC, Judith Farbey and Gemma Hobcroft, 9 March 2010. 
the resolve and the institutional machinery to deal with such issues? At least on one footing, in the light of modern scientific knowledge about variations in human sexuality, the attitudes of Commonwealth member states to their homosexual citizens are a kind of sexual apartheid. But where is the leadership and institutional machinery to intervene and to ensure that the Commonwealth can make a difference in a truly modern way on this and other human rights issues? Is the Commonwealth of Nations condemned to stumble along as an ineffective body, publishing grand declarations of human rights every two years, but, when tested, lapsing into public silence and failing to take any effective remedial measures?

\section{Conclusion}

Achieving institutional reform at a global level is an extremely difficult endeavour. So much is demonstrated by the endless arguments about reform of the United Nations and the comparatively little progress that has been made under successive secretaries-general to achieve such reform. The project now facing the EPG for the reform of the Commonwealth of Nations presents a mighty challenge. Agreeing upon and securing proposals that will gain acceptance at the CHOGM meeting in Perth in October 2011 will be difficult. Success is by no means assured. It might be expected that smaller and developing countries of the Commonwealth (which are very numerous, being 31 of the 54 classified as small states) will demand recognition by the EPG and the Commonwealth of the integral role of the 'right to development' as an element in universal human rights, and a demand that the Secretary-General of the Commonwealth become a kind of spokesperson for smaller Commonwealth states at the meetings of the new groupings of the world's richer and more powerful countries - specifically the G20. Five nations of the Commonwealth (the United Kingdom, Canada, Australia, India and South Africa) have a seat at the G20.

The proposal for a more active Commonwealth role might, however, run into resistance from the G20 themselves because of its ramifications for other potential participants. It might also run the risk of diverting the Commonwealth's attention from the present institutional challenges - namely, the better implementation of the declared values of the organisation and their translation into regular effective practical action. Should the Commonwealth not concentrate on improving the machinery it already has in place in the CMAG? Should it not first strive to uphold the values it has regularly proclaimed before it takes on other, larger economic and geopolitical challenges, however integral they might be in theory and even in practice for attainment of human rights for all Commonwealth citizens? 
This is the tricky problem that must be addressed by the EPG. Perhaps in the contrasting demands of the older, developed countries of the Commonwealth and of the younger, developing countries might lie the seeds of a common agreement. The long-term attainment of practical human rights for Commonwealth citizens will never be assured whilst poverty, homelessness, and lack of access to water, education and basic health care remain features of daily life in some Commonwealth countries. By the same token, in the face of the activities of human rights-denying countries of the Commonwealth, it might be better to exclude some of the more egregious offenders for a time until they get their human rights record and conduct into better shape. Yet, is the Commonwealth willing to face up to and decide that such action should be taken?

The dialogue of the EPG continues. Its report will be provided to the CHOGM meeting in 2011. And even when the report is produced, the adoption of any reform and its successful implementation throughout this global community will be a huge challenge. To focus on the way ahead requires concentration by the EPG on what is attainable and what can be achieved by strategic decisions. The EPG needs to heed the warnings of Eric Patashnik (2008) in his book Reforms at Risk: What happens after major policy changes are enacted. Although stated in the political context of legislation enacted by the Congress of the United States of America, much of what he says is relevant to the deliberations of the EPG in the still more difficult challenge of reform in institutions - such as the Commonwealth - that function at a global level:

'Like a child's room', writes former Treasury official Eugene Steurele, 'one has little expectation that when [the reform] is cleaned up, it will stay tidy forever. By the same token, permanent improvements can often be made along the way'. Just as parents learn to pick some battles with their children and avoid others, so idealistic yet savvy reformers must reflect on which potential reform targets are worth the effort...Because battles over reforms sometimes get caught up in broader partisan and ideological conflicts, it is easy to lose sight of the fact that reform decisions also reflect normative tensions between the values of commitment and discretion, and between the pay-off from the avoidance of foreseeable policy mistakes, on the one hand, and the payoff from the preservation of the flexibility necessary for beneficial social learning and policy evaluation on the other. The often circuitous paths that reforms take matter not only because they create winners and losers at certain moments in time, but because they shape the possibilities for governance in the future. Strategic leaders will want to think carefully about the reform legacies they leave to their successors. (Patashnik 2008:180) 
These words, written in the context of securing lasting reforms to the tax code of the United States of America, have a more general relevance. They carry a general instruction for national reformers, but also for those who seek to change international organisations to reflect more clearly the altered world in which those organisations now operate.

The alternative world of the Commonwealth of Nations is one in which the trappings and realities of British power - which once held the family togetherhave retreated almost to vanishing point as a relevant consideration. Even the trappings of British symbolism are no longer particularly potent. What is left is a body held together by history, sentiment and perceived current utility. Yet, it is a body that proclaims its allegiance to values that are vital for peace, security and equity in the world.

That is what universal, fundamental human rights represent. It is why the Commonwealth so gladly embraces these rights and asserts them as the 'core values' that it upholds. It is why it has created an organisational structure to ensure the attainment of such important values. It is difficult, in an everwatching world, to get away for long with grandiose declarations, followed up by seriously inadequate performance. Yet this is what the Commonwealth has so far stumbled along trying to do.

Reform certainly cannot be imposed against the will of the organisation. Effectively, it must be agreed to. At the heart of securing agreement is the need for conviction that - at least in a sufficient number of participating governments at CHOGM - it is in their interests, and right, that they should do so; or that the game is up and they cannot continue to go on declaring one thing and doing another: to declare human rights as a 'fundamental value' but to deny them repeatedly and so publicly in domestic policies.

The time is fast approaching when the Commonwealth must make a choice. Upon the choice that is made could depend the survival of the organisationcertainly in anything like the form it presently manifests. So much seems to be inherent in the many responses of disillusionment and despair expressed in the Commonwealth Conversation conducted by the Royal Commonwealth Society and in many other contributions urging effective institutional reform.

As a useful connection between many states and peoples that history has fortuitously presented to us, the Commonwealth of Nations is certainly worth preserving. It needs effective and lasting institutional reform, however, if it is to survive. If there is sufficient will, it should be possible to secure such lasting reforms. But is that will attainable? Or would its members rather that it atrophied into insignificance, because they were unwilling to face the painful and competing realities? If there is the will, there is the way. 
Delivering Policy Reform

\section{References}

BBC news online, 27 October 2004, 'Obasanjo backs bishops over gays'.

Commonwealth Heads of Government Meeting (CHOGM) 2009, Trinidad and Tobago Affirmation on Commonwealth Values and Principles, Commonwealth Heads of Government Meeting, 27-29 November 2009, Port of Spain, Republic of Trinidad and Tobago.

Commonwealth High Level Review Group 2002, Report by the Commonwealth High Level Review Group to the Commonwealth Heads of Government, Coolum, Australia, Department of the Prime Minister and Cabinet, Barton, ACT.

Husain, M. 2010, Commonwealth Lawyers' Association condemns Malawi gay couple imprisonment, 20 May 2010, Statement by Commonwealth Lawyers' Association President.

Johnson, R.W. and Tom Walker, March 19 2000, 'Mugabe makes new 'gay Britain' attack'. The Sunday Times.

Llango, R. Iniyan, 2010, 'CHOGM 2009, Detour or Dead End?' Commonwealth Human Rights Initiative Newsletter, vol. 17, p.2.

Mayall, J. (ed.) 2010, The Contemporary Commonwealth: An assessment, 19652009, Routledge, London.

Oke, Ayo, 2008, 'Democracy and Good Governance in Africa', Speech presented at the United Nations Workshop On Promoting Democratic Transitions in Africa, Banako, Mali, 24-25 November 2008.

Patashnik, E. M. 2008, Reforms at Risk: What happens after major policy changes are enacted, Princeton University Press, Princeton, NJ.

Ramphal, S. 2010, 'A Commonwealth of laws: at 60 and beyond', Commonwealth Law Bulletin, vol. 36, p. 359.

Royal Commonwealth Society 2009, Common What? Emerging findings of the Commonwealth Conversation, November 2009, Royal Commonwealth Society, London. 